\title{
CARACTERÍSTICAS DAS ÁGUAS DO SISTEMA AQÜÍFERO SERRA GERAL NO ESTADO DO PARANÁ ANTONIO CARLOSBUCHMANN FILHO
}

\author{
DISSERTAÇÃO DE MESTRADO - Programa de Pós-Graduação em Geologia - UFPR \\ DATA DE DEFESA: 08 nov. 02
}

\begin{abstract}
O intuito principal do presente estudo foi verificar a interconexão entre aqüíferos diferentes, analisando as características da água subterrânea do aqüífero Serra Geral no estado do Paraná. Sobre as rochas vulcânicas da Formação Serra Geral, esforços recorrentes desde o Proterozóico reativaram várias zonas de fraqueza. Esses eventos, somados às estruturas singenéticas dos derrames vulcânicos, possibilitaram a criação de um intrincado sistema de espaços abertos, por onde a água circula. Dessa forma, o estudo da água de poços tubulares profundos possibilitou caracterizar sua tipologia e relacioná-la com zonas de falhamentos e de grande incidência de diques de diabásio, identificando áreas propícias à interação entre aqüíferos diferentes. Para tanto, utilizou-se os registros de poços tubulares profundos cadastrados no Banco de Dados Hidrogeológicos cedido pela SUDERHSA - Superintendência de Desenvolvimento de Recursos Hídricos e Saneamento Ambiental do Paraná. A análise foi efetuada sobre dados físico-químicos referentes à temperatura, $\mathrm{pH}$, sólidos totais dissolvidos, bicarbonato, sulfato, cloreto, cálcio, magnésio, sódio, potássio e sílica dissolvida, assim como de dados hidrodinâmicos referentes à profundidade das contribuições de água, posição do nível estático, posição do nível dinâmico, vazão e capacidade específica de exploração. Por meio de uma filtragem sobre 2.846 regis-
\end{abstract}

tros, definiu-se 238 dados a serem utilizados, que foram separados por bacias hidrográficas de grande porte. Procedeu-se sobre esses uma análise estatística básica, obtendo-se os teores médios, a mediana, o desvio padrão, os máximos e mínimos. Foi possível caracterizar a tipologia bicarbonatada cálcica como sendo inerente ao aqüífero; a bicarbonatada mista que, por vezes, pode sugerir conexão entre aqüíferos; a bicarbonatada sódica que acompanhada de $\mathrm{pH}$ alcalino e teores de sódio acima de $19,39 \mathrm{mg} / \mathrm{L}$ é proveniente da mistura entre aqüíferos. Ocorrem também outras tipologias menos freqüentes de água, que foram relacionadas à interação de fatores como ação antrópica e mistura entre aqüíferos diferentes, sugerindo correlação com os diques de diabásio, capazes de constituir barreiras ao fluxo da água subterrânea favorecendo seu enriquecimento salino. Com base nos teores de concentração das espécies dissolvidas, foi reconhecida uma compartimentação regional que mostra teores mais baixos ao sul da zona de falha de Cândido de Abreu/Campo Mourão e teores mais altos ao norte. A distribuição das diferentes tipologias de água permitiu identificar zoneamentos hidroquímicos correlacionados com estruturas de falhamentos, sendo possível reconhecer locais preferenciais de interconexão entre aqüíferos diferentes, preferencialmente segundo a direção NW. 